\title{
RESPONSE OF SOME SUGAR BEET (Beta vulgaris L.) VARIETIES TO NITROGEN FERTILIZER IN SANDY RECLAIMED SOILS.
}

\author{
(Received:23.3.2011) \\ By \\ N.M.E. Shalaby, A.M.H. Osman* and E. M. Abdel-Fatah** \\ Variety Maintenance, Agronomy and *Physiology** Departments \\ Sugar Crops Research Institute, Agriculture Research Center, Giza, Egypt.
}

\begin{abstract}
Two field experiments were carried out at Kafr El-Hammam Research Station, Sharkia Governorate in 2008/2009 and 2009/2010 to study the effect of three nitrogen fertilizer levels (80, 100 and $120 \mathrm{~kg}$ $\mathrm{N} /$ fed.) on yield and quality of three multigerm sugar beet varieties, i.e. Gloria, Sultan and Desprez poly. Sugar beet varieties were planted by hand on the $1^{\text {st }}$ week of November and harvest was after seven months in both seasons. A split plot design in four replications was used where varieties Gloria, Sultan and Desprez poly were allocated in the main plots while subplots were nitrogen fertilizer rates. The results showed that:

1- Both sugar beet varieties and nitrogen fertilizer levels were significantly affected on some growth characters [length, diameter $(\mathrm{cm} / \mathrm{plant})$ and fresh weight $(\mathrm{g} / \mathrm{plant})$ of roots], juice quality (total soluble solids, sucrose and purity percentages), yields [top, root and sugar yields (ton fed. ${ }^{-1}$ )] and some macronutrients \% (nitrogen, phosphorus and potassium) in both seasons.

2- Sultan variety surpassed the other two varieties in root and sugar yields, and it recorded 38.77 and 35.96 (ton fed. ${ }^{-1}$ ), respectively for root yield and 6.33 and $5.29\left(\right.$ ton fed. $\left.^{-1}\right)$, respectively for sugar yield in the $1^{s t}$ and $2^{\text {nd }}$ seasons.

3- Application of (120 kg N/fed.) surpassed the other nitrogen fertilizer levels in root and sugar yields, and recorded 39.97 and $37.26\left(\right.$ ton $\mathrm{fed}^{-1}$ ), for root yield and 6.55 and 5.33 ( ton fed. ${ }^{-1}$ ), respectively for sugar yield in the $1^{s t}$ and $2^{\text {nd }}$ seasons.

Under the conditions of this investigation, using the variety 'Sultan' fertilized with $100 \mathrm{~kg} \mathrm{~N} / \mathrm{fed}$. is recommended to obtain the maximum root and sugar yield tons fed $^{-1}$.
\end{abstract}

Key words: Beta vulgaris L., nitrogen fertilizer, sandy reclaimed soils.

\section{INTRODUCTION}

All sugar beet genotypes (Beta vulgaris L.) cultivated in Egypt are imported from foreign countries, so, it is preferable to evaluate them under Egyptian conditions especially under newly reclaimed soils to select the best suited ones. Sugar beet growth is largely influenced by the agronomic practices as crop stand and fertilization, especially in the newly reclaimed soils which are characterized by low contents of organic matter and nutrients, which ultimately affect root and sugar yields. Some sugar beet genotypes have been promoted as high sugar content genotypes and are adapted for early harvest. Aly (2000) and El-Geddawy et al. (2001) in Egypt, tested three sugar beet varieties Pleno, Kawemira and Lola. They found that Lola surpassed the other two varieties in TSS\%, root and sugar yields. Badawi et al. (2002) and Osman et al. (2003) in Egypt evaluated some sugar beet cultivars i.e., Top, Lola, Pleno and Kawemira. They found that, Kawemira was superior in sucrose\%, root, top and sugar yields ton/fed. Shalaby (2003), Azzazy (2004) and Abd El-Aal and Amal (2005) indicated that two multigerm sugar beet varieties, Beta poly 4, Ras poly and two monogerm varieties, Toro and Hilx were differed significantly in root length, sucrose $\%$, root and sugar yields. Also, they added that sugar beet variety 'Ras poly' surpassed the other varieties in root length, purity $\%$, sucrose $\%$, yields of root and sugar. Aly (2006), Azzazy et al. (2007) and ElSheikh et al. (2009) showed that the evaluated sugar beet varieties varied significantly in root fresh weight, root and sugar yields, while root length and diameter as well as sucrose and 
purity\% did not differ significantly. Sugar beet variety KWS-9422 gave the highest root and sugar yields. Enan et al. (2009) found that sugar beet varieties viz Sumba, Pleno, Toro, Kawemira, Lola and Farida differed significantly in all the studied characters except TSS \% in both seasons. In addition, insignificant differences were detected among varieties in sugar yield in the $1^{\text {st }}$ season. Farida variety gave the highest value in root length, diameter and fresh weight and root yield. On the other hand, Lola variety came the second in sugar yield and quality parameters (TSS, sucrose and purity \%) after Sumba. Several workers studied the effect of nitrogen fertilizer on sugar beet yield and quality. Shafika and Darwish (2001) revealed that sucrose and juice purity \% were reduced linearly as $\mathrm{N}$ level was increased. On the contrary, total soluble solids (TSS \%) was increased by increasing $\mathrm{N}$ level. Nemeat Alla (2004) stated that applying 20, 40 and $60 \mathrm{~kg} \mathrm{~N} / \mathrm{fed}$ had no effect on sugar beet root length and increasing $\mathrm{N}$ level to $140 \mathrm{~kg} / \mathrm{fed}$. did not affect sucrose and TSS\%. Abou Zeid and Osman (2005) and Aly et al. (2009) found that the highest sugar yield was obtained by adding $80 \mathrm{~kg} \mathrm{~N} / \mathrm{fed}$. While, insignificant differences were recorded on TSS, sucrose and purity\% in both seasons. Pytlarzkozicka (2005) found that an increase of nitrogen rate from 90 to $180 \mathrm{~kg} \mathrm{~N} /$ ha caused a significant increase of average root mass, leaves and dry matter yields, potassium and nitrogen content in roots, but sugar content decreased. Abu El-Fotoh and Abou El-Magd (2006) found that the highest root yields (34.26 and 33.89 ton/fed.) were recorded when urea fertilizer was applied at $80 \mathrm{~kg}$ $\mathrm{N} /$ fed. in the $1^{\text {st }}$ and $2^{\text {nd }}$ seasons, respectively.

The aim of this investigation was to evaluate the effect of nitrogen fertilizer levels on yield and quality of some sugar beet cultivars under sandy reclaimed soils.

\section{MATERIALS AND METHODS}

Two field experiments were carried out at Kafr El-Hammam Research Station, Sharkia
Governorate in 2008/2009 and 2009/2010 to study the effect of three mineral nitrogen fertilizer levels (80, 100 and $120 \mathrm{~kg} \mathrm{~N} / \mathrm{fed}$.) on yield and quality of three multigerm sugar beet varieties; Gloria, Sultan and Desprez poly. These varieties were planted by hand on the $1^{\text {st }}$ week of November and harvested after seven months in both seasons. A split plot design with four replications was used. The varieties were allocated in the main plots, while, nitrogen fertilizer levels were distributed at random in subplots. Plot area was $\left(21.60 \mathrm{~m}^{2}\right.$ 1/194/fed.) including six rows of $60 \mathrm{~cm}$ width, 20 $\mathrm{cm}$ between hills and $6 \mathrm{~m}$ long. During seed bed preparation calcium super phosphate $\left(15.5 \% \mathrm{P}_{2} \mathrm{O}_{5}\right)$ was applied at the rate of. $30 \mathrm{~kg} \mathrm{P}_{2} \mathrm{O}_{5} / \mathrm{fed}$. Nitrogen fertilizer levels $(80,100$ and $120 \mathrm{~kg} \mathrm{~N}$ /fed.) were applied in the form of ammonium nitrate $(33.5 \% \mathrm{~N})$ at four equal doses. The $1^{s t}$ one was added after thinning and 15 days between the other doses. Potassium sulfate $\left(48 \% \quad \mathrm{~K}_{2} \mathrm{O}\right)$ was added at the rate of $36 \mathrm{~kg} \mathrm{~K} \mathrm{~K}_{2} \mathrm{O}_{5}$ /fed. after thinning. Soil samples were taken before sowing and were prepared for the determination of physical and chemical soil properties according to Page (1982) (Table 1).

The previous crop was maize in both seasons; thereafter seeds were sown and irrigated immediately. Other agricultural practices were done as recommended by Sugar Crops Research Institute.

\subsection{Recorded data}

Sugar beet plants of the two guarded rows were uprooted, topped, weighed and a random sample of ten roots was taken from each sub-plot to determine: average root length and diameter $(\mathrm{cm} /$ plant $)$, average root fresh weight (g/plant), total soluble solids (T.S.S.\%) which was determined by using Hand Refractometers, sucrose \% was polarimetrically determined according to the methods of Le-Docte (1927), juice purity \% which was determined according to the following equation : Juice purity $\%=($ Sucrose $\% /$ total soluble solids\%) x 100 , top, root and sugar yields $\left(\right.$ ton $\left.\mathrm{fed}^{-1}\right)$, Sugar yield $\left(\right.$ ton fed $\left.\mathrm{f}^{-1}\right)=$ root yield $($ ton

Table (1). Physical and chemical analyses of the experimental soil

\begin{tabular}{|c|c|c|c|c|c|c|c|c|c|c|c|}
\hline \multirow{2}{*}{ Season } & \multicolumn{3}{|c|}{ Mechanical analysis } & \multirow{2}{*}{\multicolumn{2}{|c|}{ Soil texture }} & \multirow{2}{*}{\multicolumn{2}{|c|}{ E.C ds/m }} & \multirow{2}{*}{ Soil pH* } & \multirow{2}{*}{\multicolumn{2}{|c|}{$\begin{array}{c}\text { Organic } \\
\text { matter\% }\end{array}$}} & \multirow[b]{2}{*}{$\mathrm{CaCO}_{3}$} \\
\hline & Sand \% & Silt \% & Clay \% & & & & & & & & \\
\hline $2008 / 2009$ & 64.00 & 23.00 & 13.00 & \multicolumn{2}{|c|}{ Sandy } & \multicolumn{2}{|l|}{0.89} & 8.20 & \multicolumn{2}{|c|}{1.20} & 3.00 \\
\hline & 64.20 & 22.70 & 13.10 & \multicolumn{2}{|c|}{ Sandy } & 0.87 & & 8.00 & \multicolumn{2}{|c|}{1.30} & 2.98 \\
\hline \multirow{2}{*}{ Season } & \multicolumn{4}{|c|}{ Soluble cations $(\mathrm{meq} / \mathrm{L})$} & \multicolumn{4}{|c|}{ Soluble anions (meq/L) } & \multicolumn{3}{|c|}{ Available nutrients(ppm) } \\
\hline & $\mathrm{Ca}^{++}$ & $\mathrm{Mg}^{++}$ & $\mathrm{Na}^{+}$ & $\mathbf{K}^{+}$ & $\mathrm{CO}_{3}^{--}$ & $\mathrm{HCO}_{3}^{-}$ & $\mathrm{Cl}^{-}$ & $\mathrm{SO}_{4}^{--}$ & $\mathbf{N}$ & $\mathbf{P}$ & $\mathbf{K}$ \\
\hline & 2.00 & 200 & & & & & 6.00 & & & 22.2 & 55.30 \\
\hline $2009 / 2010$ & 2.11 & 3.02 & 3.97 & 0.20 & 0.00 & 0.69 & 5.98 & 2.63 & 16.42 & 21.33 & 50.00 \\
\hline
\end{tabular}

* Soil pH in 1:2.5 soil: water suspension 
fed $\left.^{-1}\right) \mathrm{x}$ (sucrose \% / 100) and Macro elements i.e. nitrogen, phosphorus and potassium \% were determined according to A.O.A.C. (1990).

\section{Statistical analysis}

Analysis of variance was made according to the method described by Snedecor and Cochran (1980). Least significant difference test (LSD) at $5 \%$ level of significance was used to compare means.

\section{RESULTS AND DISCUSSION \\ 3.1. Effect of sugar beet varieties \\ 3.1.1. Effect on root growth characters}

The results given in Table (2) revealed that the average of sugar beet root length and diameter $(\mathrm{cm})$, as well as the average of root fresh weight (g/ plant) were significantly affected by the studied sugar beet cultivars in both seasons. Sultan variety surpassed the other two varieties in root dimension and root fresh weight followed by Disperz poly in both seasons.

These results are in harmony with those found by $\mathrm{Al}$-Labbody (2003) and El-Geddawy et al. (2006). The difference among the three sugar beet varieties could be due to the variation in the gene make-up and their response to the environmental conditions.

\subsubsection{Effect on juice quality}

The results given in Table (2) indicate that the differences among sugar beet cultivars in sucrose, total soluble solid and purity $\%$ were significant in the two seasons, except the difference between Gloria and Disperz poly varieties in purity $\%$ in the ${ }^{\text {st }}$ season and between Sultan and Gloria varieties in sucrose and purity $\%$ in the $2^{\text {nd }}$ season. Sultan recorded the highest values (16.49 and $14.70 \%)$ of sucrose in the $1^{\text {st }}$ and $2^{\text {nd }}$ seasons, respectively and the highest value $(21.48 \%)$ of T.S.S in the $1^{\text {st }}$ season and of purity $(79.05 \%)$ in the $2^{\text {nd }}$ season, whereas Desprez poly variety was superior over the other two varieties in purity $(81.63 \%)$ in the $1^{\text {st }}$ season and in T.S.S $(19.87 \%)$ in the $2^{\text {nd }}$ season. This finding is in line with that found by El-Geddawy et al. (2006) who found that Sultan variety recorded the highest sucrose \% compared with the other varieties in both seasons.

\subsubsection{Effect on Macro-nutrients composition of beet root}

The results in Table (3) reveal that the evaluated verieties differed significantly in their macro nutrient contents in both seasons, except the difference between Sultan and Desprez poly varieties in $\mathrm{P} \%$ in the $1^{\text {st }}$ season and in $\mathrm{K} \%$ in the $2^{\text {nd }}$ season. Sultan recorded the highest values of
$\mathrm{N} \%$ and $\mathrm{P} \%$ in the $1^{\text {st }}$ season. While in the $2^{\text {nd }}$ season Desprez poly variety gave the highest value of $\mathrm{N} \%$ as well as Gloria variety recorded the highest $\mathrm{P} \%$ and $\mathrm{K} \%$.

\subsubsection{Effect on yields of top, root and sugar} (tons fed ${ }^{-1}$.)

The data in Table (3) show a significant difference among the tested sugar beet cultivars in top, root and sugar yields in both seasons, except the difference between Sultan and Desprez poly varieties in root and sugar yields in both seasons and in top yield in the $1^{\text {st }}$ season only; where differences did not reach to the significant level. Sultan overpassed the other two varieties for top, root and sugar yields. The same trend was found by Al-Labbody (2003) and El- Geddawy et. al. (2006). They reported that top, root and sugar yields showed a marked variation among varieties. Sultan was superior than the other varieties in root and sugar yields.

\subsection{Effect of nitrogen fertilizer levels \\ 3.2.1. Effect on root growth characters}

The data in Table (4) show that $\mathrm{N}$ - fertilizer levels had significant effect on averages root length, diameter and root fresh weight, in both seasons. The highest values of root length, diameter and fresh weight were obtained from 120 $\mathrm{kg} \mathrm{N} / \mathrm{fed}$. in the two seasons. Whereas, the lowest values were obtained from applying $80 \mathrm{~kg} \mathrm{~N} / \mathrm{fed}$. in both seasons, with insignificant differences between 80 and $100 \mathrm{~kg} \mathrm{~N} /$ fed. for root length in the $1^{\text {st }}$ season only. Raising $\mathrm{N}$ levels from 80 to 100 and from 100 to $120 \mathrm{~kg} \mathrm{~N} /$ fed. increased root fresh weight by 20.45 and $25.44 \mathrm{~g} /$ plant, respectively in the $1^{s t}$ season, corresponding to 44.11 and $45.11 \mathrm{~g} / \mathrm{plant}$, respectively in the $2^{\text {nd }}$ season (Table, 4). The increase in root dimension could be due to stimulation effect of nitrogen on building up new cells, cell division and cell enlargement and also to the role of nitrogen in encouraging plant uptake of the other elements and activate accumulation of carbohydrates, which in turn enhanced root fresh weight per plant (Zeinab et al., 2000). These results are in line with those of Ibrahim et al. (2005), El- Sheref (2006), Nemeat Alla et al. (2007), El- Geddawy et al. (2008) and El-Sarag (2009).

\subsubsection{Effect on juice quality}

Increasing N-level from 80 to $120 \mathrm{~kg} \mathrm{~N} / \mathrm{fed}$. significantly increased T.S.S \% from 20.32 to $20.82 \%$, in the $1^{s t}$ season and from 19.32 to $19.48 \%$, in the $2^{\text {nd }}$ season, respectively.

Sucrose $\%$ was also increased by increasing Nlevel from 80 to $120 \mathrm{~kg} \mathrm{~N} / \mathrm{fed}$. with insignificant differences between 100 and $120 \mathrm{~kg} \mathrm{~N} / \mathrm{fed}$. in both 
Table (2): Effect of sugar beet varieties on some root growth characters and juice quality \% at harvest in 2008/2009 and 2009/2010 seasons.

\begin{tabular}{|c|c|c|c|c|c|c|}
\hline \multicolumn{7}{|c|}{$2008 / 2009$} \\
\hline Characters & \multicolumn{3}{|c|}{ Root growth characters } & \multicolumn{3}{|c|}{ Juice quality \% } \\
\hline $\begin{array}{l}\text { Sugar beet } \\
\text { varieties }\end{array}$ & $\begin{array}{c}\text { Length } \\
\text { (cm/plant) }\end{array}$ & $\begin{array}{l}\text { Diameter } \\
\text { (cm/plant) }\end{array}$ & $\begin{array}{c}\text { Fresh } \\
\text { weight } \\
\text { (g/plant) }\end{array}$ & $\begin{array}{c}\text { Total } \\
\text { soluble } \\
\text { solids }\end{array}$ & Sucrose & Purity \\
\hline Gloria & 35.49 & 15.69 & 1176.67 & 19.59 & 15.51 & 79.41 \\
\hline Sultan & 38.22 & 18.32 & 1373.78 & 21.48 & 16.49 & 75.31 \\
\hline Desprez poly & 36.90 & 17.09 & 1281.22 & 20.57 & 16.06 & 81.63 \\
\hline LSD $5 \%$ & 0.90 & 0.85 & 90.10 & 0.65 & 0.15 & 2.30 \\
\hline \multicolumn{7}{|c|}{$2009 / 2010$} \\
\hline Gloria & 31.47 & 14.30 & 1072.22 & 19.21 & 14.54 & 76.82 \\
\hline Sultan & 34.02 & 16.85 & 1263.56 & 18.78 & 14.70 & 79.05 \\
\hline Desprez poly & 33.06 & 15.89 & 1191.22 & 19.87 & 13.96 & 70.56 \\
\hline LSD 5\% & 0.66 & 0.55 & 52.50 & 0.13 & 0.20 & 3.00 \\
\hline
\end{tabular}

Table (3):Effect of sugar beet varieties on top, root and sugar yields (ton fed ${ }^{-1}$ ) and macro element \% in roots at harvest in $2008 / 2009$ and $2009 / 2010$ seasons.

\begin{tabular}{|c|c|c|c|c|c|c|}
\hline \multicolumn{7}{|c|}{ 2008/2009 } \\
\hline Characters & \multicolumn{1}{|c|}{ Macro elements \% } & \multicolumn{3}{c|}{ Yields ( ton fed ${ }^{-1}$ ) } \\
\hline $\begin{array}{c}\text { Sugar beet } \\
\text { varieties }\end{array}$ & $\mathbf{N}$ & $\mathbf{P}$ & $\mathbf{K}$ & Top & Root & Sugar \\
\hline Gloria & 1.03 & 0.39 & 1.48 & 16.78 & 37.66 & 5.88 \\
\hline Sultan & 1.08 & 0.46 & 1.52 & 18.57 & 38.77 & 6.33 \\
\hline Desprez poly & 1.06 & 0.45 & 1.56 & 18.26 & 38.54 & 6.24 \\
\hline LSD 5\% & 0.01 & 0.02 & 0.03 & 0.80 & 0.45 & 0.12 \\
\hline \multicolumn{7}{|c|}{$\mathbf{2 0 0 9 / 2 0 1 0}$} \\
\hline Gloria & 1.10 & 0.48 & 1.54 & 15.27 & 33.95 & 4.56 \\
\hline Sultan & 1.09 & 0.42 & 1.50 & 18.01 & 35.96 & 5.29 \\
\hline Desprez poly & 1.15 & 0.43 & 1.50 & 16.92 & 35.27 & 5.14 \\
\hline LSD 5\% & 0.01 & 0.01 & 0.02 & 0.77 & 1.22 & 0.49 \\
\hline
\end{tabular}

Table (4): Effect of nitrogen fertilizer levels on some growth characters of roots and juice quality $\%$ at harvest in $2008 / 2009$ and $2009 / 2010$ seasons.

\begin{tabular}{|c|c|c|c|c|c|c|}
\hline \multicolumn{7}{|c|}{ 2008/2009 } \\
\hline Characters & \multicolumn{2}{|c|}{ Root growth characters } & \multicolumn{3}{c|}{ Juice quality \% } \\
\hline $\begin{array}{c}\text { Nitrogen } \\
\text { levels (N/fed.) }\end{array}$ & $\begin{array}{c}\text { Length } \\
\text { (cm) }\end{array}$ & $\begin{array}{c}\text { Diameter } \\
\text { (cm) }\end{array}$ & $\begin{array}{c}\text { Fresh } \\
\text { weight } \\
\text { (g/plant) }\end{array}$ & $\begin{array}{c}\text { Total } \\
\text { soluble } \\
\text { solids }\end{array}$ & Sucrose & Purity \\
\hline $\mathbf{8 0}$ & 36.54 & 16.74 & 1255.11 & 20.32 & 15.57 & 78.30 \\
\hline $\mathbf{1 0 0}$ & 36.80 & 17.01 & 1275.56 & 20.50 & 15.97 & 78.25 \\
\hline $\mathbf{1 2 0}$ & 37.27 & 17.35 & 1301.00 & 20.82 & 16.51 & 79.82 \\
\hline LSD 5\% & 0.32 & 0.27 & 20.10 & 0.12 & 0.72 & 0.02 \\
\hline \multicolumn{7}{|c|}{$\mathbf{2 0 0 9 / 2 0 1 0}$} \\
\hline $\mathbf{8 0}$ & 32.26 & 15.09 & 1131.22 & 19.32 & 13.54 & 70.57 \\
\hline $\mathbf{1 0 0}$ & 32.84 & 15.68 & 1175.33 & 19.06 & 14.48 & 78.67 \\
\hline $\mathbf{1 2 0}$ & 33.44 & 16.28 & 1220.44 & 19.48 & 15.17 & 77.19 \\
\hline LSD 5\% & 0.12 & 0.16 & 22.15 & 0.11 & 0.70 & 3.35 \\
\hline
\end{tabular}


Table (5). Effect of nitrogen fertilizer levels on top, root, and sugar yields (ton fed ${ }^{-1}$ ) and macro element $\%$ in roots at harvest in $2008 / 2009$ and $2009 / 2010$ seasons.

\begin{tabular}{|c|c|c|c|c|c|c|}
\hline \multicolumn{9}{|c|}{ 2008/2009 } \\
\hline Characters & \multicolumn{3}{|c|}{ Macro elements \% } & \multicolumn{3}{c|}{ Yields (ton fed $^{-1}$ ) } \\
\hline $\begin{array}{c}\text { Nitrogen levels } \\
\text { (N/fed.) }\end{array}$ & $\mathbf{N}$ & $\mathbf{P}$ & $\mathbf{K}$ & Top & Root & Sugar \\
\hline $\mathbf{8 0}$ & 1.02 & 0.41 & 1.50 & 17.56 & 35.30 & 5.50 \\
\hline $\mathbf{1 0 0}$ & 1.03 & 0.47 & 1.49 & 17.84 & 39.70 & 6.40 \\
\hline $\mathbf{1 2 0}$ & 1.11 & 0.43 & 1.58 & 18.20 & 39.97 & 6.55 \\
\hline LSD 5\% & 0.05 & 0.05 & 0.07 & 0.40 & 0.84 & 0.31 \\
\hline \multicolumn{7}{|c|}{$\mathbf{2 0 0 9 / 2 0 1 0}$} \\
\hline $\mathbf{8 0}$ & 1.12 & 0.39 & 1.49 & 16.07 & 32.18 & 4.73 \\
\hline $\mathbf{1 0 0}$ & 1.10 & 0.44 & 1.51 & 16.74 & 35.75 & 5.17 \\
\hline $\mathbf{1 2 0}$ & 1.12 & 0.49 & 1.54 & 17.39 & 37.26 & 5.33 \\
\hline LSD 5\% & 0.01 & 0.03 & 0.02 & 0.37 & 1.11 & 0.23 \\
\hline
\end{tabular}

seasons and between 80 and $100 \mathrm{~kg} \mathrm{~N} / \mathrm{fed}$. in the $1^{\text {st }}$ season (Table 4). Increasing N-level from 80 to $120 \mathrm{~kg} \mathrm{~N} / \mathrm{fed}$. significantly increased purity \% from 78.30 to $79.82 \%$ in the $1^{\text {st }}$ season and from 70.57 to $77.19 \%$ in the $2^{\text {nd }}$ season, respectively. Insignificant decrease in purity $\%$ was found when $\mathrm{N}$ fertilizer level was increased from 100 to 120 $\mathrm{kg} \mathrm{N} / \mathrm{fed}$. in the $2^{\text {nd }}$ season. This may be due to the increases of amino compound concentrations caused by excessive uptake of nitrate late in the season. These results agree with those recorded by El- Sarag (2009). who reported that, increasing N fertilizer rates from 60 up to $120 \mathrm{~kg} \mathrm{~N} /$ fed increased T.S.S \% and depressed sucrose and purity percentages. The insignificant increase of sugar (Table 4) may be due to $(\mathrm{N})$ fertilizer increase fraction of the sucrose $\%$ assimilate entering the root that was used in growth at the expense of that stored as sugar (Milford and Watson 1971).

\subsubsection{Effect on Macro-nutrients composition of beet root}

The results in (Table 5) showed a significant increase in nitrogen $(\mathrm{N})$, phosphorus $(\mathrm{P})$ and potassium $(\mathrm{K})$ percentages in the two seasons as affected by increasing the levels of (N). Application of $120 \mathrm{~kg} / \mathrm{fed}$. gave the highest (N and $\mathrm{K} \%$ ) in both seasons, and $\mathrm{P} \%$ in the $2^{\text {nd }}$ season only, whereas, adding (100 kg N/fed.) gave the highest $\mathrm{P} \%$ in the $1^{\text {st }}$ season. Such effect may be due to that $(\mathrm{N})$ dressing enhanced the uptake of other elements which finally reflected in a better growth (Zeinab et al., 2000). These results are in accordance with those obtained by Abou Zeid and Osman (2005) and Aly et al. (2009).

\subsubsection{Effect on yields of top, root and sugar (ton fed $^{-1}$.)}

The results given in (Table 5) demonstrated that top, root and sugar yields (ton $\mathrm{fed}^{-1}$ ) significantly responded to the additional doses of nitrogen $\mathrm{N} / \mathrm{fed}$. with insignificant differences between 100 and $120 \mathrm{~kg} \mathrm{~N} / \mathrm{fed}$. in the $1^{\text {st }}$ seasons while, in the $2^{\text {nd }}$ season the differences between 100 and $120 \mathrm{~kg} \mathrm{~N} /$ fed. in top and root yields were significant. The highest $\mathrm{N}$ - level $(120 \mathrm{~kg} \mathrm{~N} / \mathrm{fed}$.) increased root yield by 13.23 and $15.79 \%$ and sugar yield by 19.09 and $12.68 \%$ in the $1^{s t}$ and $2^{\text {nd }}$ seasons, respectively as compared with the lowest level ( $80 \mathrm{~kg} \mathrm{~N} / \mathrm{fed}$.).

The differences between 100 and $120 \mathrm{~kg}$ $\mathrm{N} / \mathrm{fed}$. had insignificant effect on sugar yield tons/ fed. in both seasons, so that adding N-fertilizer more than $100 \mathrm{~kg} \mathrm{~N} / \mathrm{fed}$. will not be of economic value for maximizing sugar yield. These findings are in agreement with those obtained by ElGeddawy et al. (2006), Nemeat Alla et al. (2007), Seadh (2008) and El- Sarag (2009). The increases in root yield by increasing $\mathrm{N}$-level may be due to the role of nitrogen in accumulating carbohydrates, translocated from leaves to roots which in turn enhanced root fresh weight (Table 4) and finally root and sugar yields per unit area.

Table (6). Effect of interaction between sugar beet varieties and nitrogen fertilizer levels on sucrose, sugar yield (ton fed $^{-1}$.) and phosphorus \% at harvest in 2009/2010 season.

\begin{tabular}{|l|c|c|c|}
\hline \multicolumn{4}{|c|}{ 2009/2010 season } \\
$\begin{array}{c}\text { Sugar beet varieties x } \\
\text { nitrogen fertilizer levels }\end{array}$ & $\begin{array}{c}\text { Sucro } \\
\text { se \% }\end{array}$ & $\begin{array}{c}\text { Sugar } \\
\text { yield (ton } \\
\text { fed }^{-1} \text { ) }\end{array}$ & $\begin{array}{c}\text { Phosph } \\
\text { orus } \\
\%\end{array}$ \\
\hline Gloria x 80 kg N/fed. & 14.11 & 4.42 & 0.423 \\
\hline Gloria x 100 kg N/fed. & 14.99 & 5.25 & 0.490 \\
\hline Gloria x 120 kg N/fed. & 14.25 & 4.53 & 0.513 \\
\hline Sultan x 80 kg N/fed. & 13.86 & 4.65 & 0.347 \\
\hline Sultan x 100 kg N/fed. & 15.55 & 5.76 & 0.437 \\
\hline Sultan x 120 kg N/fed. & 15.73 & 5.78 & 0.383 \\
\hline Desprez poly x 80_kg N/fed. & 12.65 & 4.60 & 0.410 \\
\hline Desprez poly x100 kg N/fed. & 14.20 & 5.11 & 0.487 \\
\hline Desprez poly x120_kg N/fed. & 14.24 & 5.62 & 0.460 \\
\hline LSD 5\% & 0.97 & 1.40 & 0.05 \\
\hline
\end{tabular}




\subsection{The interaction effect}

The interaction between the studied varieties and nitrogen fertilizer levels had a significant effect on sucrose $\%$, sugar yield $\left(\right.$ ton fed $^{-1}$ ) and $\mathrm{P}$ $\%$ in the $2^{\text {nd }}$ season only (Table 6 ).

The highest values of sucrose $\%$ and sugar yield (ton $\mathrm{fed}^{-1}$ ) were obtained by using Sultan variety and fertilized by $\mathrm{N}$ application at a level $120 \mathrm{~kg} \mathrm{~N} / \mathrm{fed}$.

\section{REFERENCES}

Abd El-Aal A.M. and Mohamed Amal Z.A. (2005). Genotype x Environment interaction and stability analysis for yield and quality of some sugar beet genotypes. Annals of Agric. Sc., Moshtohor, 43 (2): 527-544.

Abou El- Fotoh H.G. and Abou El- Magd B.M. (2006). Sugar beet productivity and quality as affected by $\mathrm{N}$ sources and rates. Egypt J. Appl. Sci., 21 (5): 375-386.

Abou Zeid M.Y. and Osman M.S.H. (2005). Yield and quality of sugarbeet as affected by bio and mineral fertilization. Egypt. J. of Appl. Sci., 20 (8B): 416-433.

Al-Labbody A. H. S. (2003). Evaluation of some multigerm and monogerm sugar beet varieties under Fayoum Governorate conditions. Ph.D. Thesis, Agron. Dept., Fac. Agric., Al-Azhar Univ.

Aly E.F. (2000). Factors affecting yield of some sugar beet varieties in newly reclaimed soils. M. Sc. Thesis, Fac. Agric., Cairo Univ.

Aly E.F. (2006). Effect of environmental conditions on productivity and quality of some sugar beet varieties. Ph. D. Thesis, Fac. of Agric., Banha Univ., Egypt.

Aly M.H.A., Moustafa Z. R. and Osman A.M.H. (2009). Effect of seed inoculation and foliar application with Azospirillum brasiliense and/or Bacillus megatherium on productivity and quality of sugar beet. Egypt. J. Appl. Sci.; 24 (2A): 56-70.

A.O.A.C. (1990). Official Methods of Analysis. Association of Official Analysis Chemist. $15^{\text {th }}$ Ed Washington U.S.A.

Azzazy N.B. (2004). Yield and quality of some sugar beet varieties as affected by water quality and nitrogen fertilization. Egypt. J. Agric. Res., 82 (4): 1733-1745.

Azzazy N.B., Shalaby N.M.S. and Abd El-Razek A.M. (2007). Effect of planting density and days to harvest on yield and quality of some sugar beet varieties under Fayoum Governorate conditions. Egypt J.of Appl. Sci. Vol.22 No. (12A): 101-114.
Badawi M.A., El-Moursy S.A., Mohamed Z.A. and Arafa A.A. (2002). Performance of some sugar beet Beta vulgaris, L. cultivars to planting dates. Pro. Minia $1^{\text {st }}$ Conf. for Agric. and Environ. Sci., Minia, Egypt, March 25-28.

El-Geddawy I.H., El- Keredy M.S., Omar A.M. and El-Moghazy A.(2008). Growth and chemical constituents of sugar beet as affected by nitrogen sources and rates and boron fertilizer. Proc. Int. Conf. "Meeting the Challenge of Sugar Crops \& Integrated Industries in Developing Countries", 11-14 Sept. Al-Arish, Egypt, : 75-82.

El-Geddawy I.H., El Shafai A.M.A. and Azzazy N.B. (2006). Yield and quality of some sugar beet varieties as affected by planting densities and nitrogen fertilization. J. Agric. Sci., Mansoura Univ., 31(1): 43-54.

El-Geddawy I.H., Laila M.S. and Abd El-Latief F.A. (2001). Hoeing and nitrogen fertilization with respect to quality, yield components of some sugar beet varieties grown in Upper Egypt. J. Agric. Sci., Mansoura Univ.,26 (8): 467-4621.

El-Sarag E.I. (2009). Maximizing sugar beet yield, quality and water use efficiency using some agricultural practices in North Sinai conditions. Bull. Fac. Agric., Cairo Univ. 60: 155-167.

El-Sheikh S.R.E., Khaled K.A.M. and Enan S.A.A.M. (2009). Evaluation of some sugar beet varieties under three harvesting dates. J. Agric. Sci., Mansoura Univ., 34 (3): 15591567.

El-Sheref E.E.M. (2006). Effect of potassium and nitrogen fertilizer on yield and quality of sugar beet (Beta vulgaris, L.) grown in North Delta. J. Agric. Sci. Mansoura Univ., 31(8): 48854899.

Enan S.A.A.M., El-Sheikh S.R.E. and Khaled, K.A.M. (2009). Evaluation of some sugar beet varieties under different levels of $\mathrm{N}$ and $\mathrm{Mo}$ fertilization. J. Biol. Chem. Environ. Sci., 4 (1): 345-362.

Ibrahim M.M., El-Aref K.A.O. and Abo ElHamed A.S. (2005). Effect of nitrogen and phosphorus fertilization on yield and quality of two sugar beet varieties under Assuit Governorate conditions. Zagazig J. Agric. Res., 32 (4): 1087-1103.

Le- Docte A. (1927). Commercial determination of sugar beet in beet root using the Sachs Le Docte process. Int. Sug. J. 29: 488-492.

Milford G.F. and Watson D.J. (1971). The effect of nitrogen on the growth and sugar content of sugar beet. Ann. Bot. 35, 287-300. 
Moustafa Sh. N. and Darwish S.D. (2001). Biochemical studies on the efficiency use of some $\mathrm{N}$ fertilizers for sugar beet production. J. Agric. Sci. Mansoura Univ. 26 (4): 2421-2439.

Moustafa Z. R., Moustafa Sh. N., Gerges M.B. and Aboushady K.A. (2000). Influence of nitrogen fertilizer on some quality, technological aspects, productivity and amino acids accumulation of sugar beet. J. Agric. Sci. Mansoura Univ. 25 (8): 4795-4806.

Nemeat Alla E.A.E (2004). Effect of some agronomic practices on yield and quality of sugar beet. M.Sc. Thesis, Fac. Agric., Tanta Univ., Egypt.

Nemeat Alla E.A.E, Aboushdy K.A. and Nariman O.A. Yousef (2007). Sugar beet yield and quality as affected by sowing patterns and nitrogen levels. J. Agric. Sci. Mansoura Univ., 32(10): 8069-8078.

Osman A.M.H., El-Sayed G.S., Osman M.S.H. and El-Sogheir K.S. (2003). Soil application of some microelements with relation to yield and quality of sugar beet varieties. Annals of Agric. Sc., Moshtohor, 41 (3): 1071-1088.

Page A.L. (1982). Methods of Soil Analysis. Chem. and Micro. Properties. $2^{\text {nd }}$ Ed., Agron 9, Am. Soc. Agron. Inc. Publ. Madison, Wis, USA.

Pytlarzkozicka M. (2005). The effect of antifungal plant protection on sugar beet yielding. Plant Soil Environ., 51 (5): pp. 232-236.

Seadh S.E. (2008). Some factors affecting sugar beet productivity under newly reclaimed sandy soils. Proc. Int. Conf. "Meeting the Challenge of Sugar Crops \& Integrated Industries in Developing Countries", 11-14 Sept. Al- Arish, Egypt, : 110-115.

Shalaby N.M. (2003). Effect of environmental conditions on the behavior of different genotypes of sugar beet root yield and quality. Ph.D. Thesis, Fac. of Agric., Al-Azhar Univ., Egypt.

Snedecor G.W. and Cochran W.G. (1980). Statistical Methods. 7 ed., Iowa State Univ. Press, Ames, Iowa, USA, pp 255-269.

\footnotetext{
إستجابة بعض أصناف بنجر السكر للتسميد النيتروجينى فى الأراضى الرملية المستصلحة 